\title{
PERJANJIAN SYARIAH PADA LEMBAGA KEUANGAN SYARIAH
}

\author{
Saidurrahman*
}

\begin{abstract}
Syan'ah is considered by many as theidkel form of soial-as udl as finanial-orda, it isnonethdessnot immmefrompractical andpehapstechnical problems, so to speek. With regards to the Syari'ah finance, cases on the ground showthat transaction involvingdispately different parties dbes atten ocar. This disputehas nothingto db with the Syari'ah itself indeed, but with the way it is applied Syan'ah howeer antiapates thisdispute to happen, conceming which this paper is interested. It is concemed with disassing this antiapation andin what wayd dos Syan'ah offer theway-aut toresdvesuch a disputein matters reating to finandal contrad. The paper argues that theability of such systemas Syan'ah to resdve problens and offer solution for disputes can bean indicator whether thesystem can be judged as an ideal or not. One of thetehniques that theSyan'ah has offeed in degling with dispateis what it calls Musyavarah (negdiation); a teehniquethat in fact has been regulated in theIndonesian law Thistechniquewill alsobeinvetigatedin this paper.

Keywords: Syan'ahlaw Syar'ahfinance, disputes
\end{abstract}

\section{Pendahuluan}

Pada masa sekarang ini, ekonomi Islam dengan segala bentuknya seperti perbankan dan pengelolaan lembaga keuangan syariah lainnya telah berkembang pesat di seluruh dunia tidak terkecuali di Indonesia. Perkembangan ini ditandai dengan terjadinya perubahanperubahan dalam berbagai bentuk transaksi ekonomi dan perdagangan. Salah satu bentuk dari perubahan ini adalah lahirnya berbagai macam perjanjian baik yang bersifat bilateral maupun multilateral. D ampak dari kemajuan ini adalah kemungkinan terjadinya salah paham dan perselisihan serta pertentangan di antara para pihak yang melakukan perjanjian tersebut.

Sebuah konflik terjadi apabila dua pihak atau lebih dihadapkan pada perbedaan kepentingan kemudian berkembang menjadi sebuah sengketa. Pihak yang merasa dirugikan selanjutnya menyatakan rasa tidak puas atau keprihatinannya, baik secara langsung kepada pihak yang dianggap sebagai penyebab kerugian atau kepada pihak lain. ${ }^{1}$ Namun sebenarnya sudah menjadi naluri setiap individu untuk menyelesaikan masalah atau sengketa dengan orang lain dengan cara tenteram dan adil karena dengan cara tersebut akan menghilangkan akibat buruk dari persengketaan tersebut. Gunawan Widjaja menyatakan bahwa setiap masyarakat memiliki berbagai macam cara memperoleh kesepakatan dalam proses perkara atau menyelesaikan sengketa dan konflik. ${ }^{2}$

Cara penyelesaian yang dipakai pada suatu sengketa tentu memiliki konsekuensi bagi para pihak yang bersengketa maupun masyarakat luas. Mekanisme penyelesaian sengketa akhirnya menjadi tolok ukur yang tepat bagi mereka yang bersengketa apakah sengketa

\footnotetext{
*Institut Agama Islam Negeri (IAIN) Sumatera Utara. 'Siti Megadianty Adam dan Takdir Rahmadi, "Sengketa dan Penyelesaiannya," BuldianMusyauarah No. 1, Thn. 1 (Jakarta: Indonesian Centre for E nvironmental Law, 1997), 1.

${ }^{2}$ G unawan Widjaja dan A hmad Yani, Seri HukumBisnis HukumArbitrase(Jakarta: PT. RajaG rafindo Persada, 2001), 3.
} 
tersebut akan diselesaikan secara damai atau tidak. Bagi masyarakat hukum Indonesia dikenal adanya dua cara dalam menyelesaikan sengketa, yaitu dengan cara musyawarah untuk mufakat dan melalui lembaga peradilan. D alam kaitan ini, penulis mencoba melihat tradisi penyeleaian sengketa dalam Islam serta peraturan perundang-undangan mengenai alternatif penyelesaian sengketa baik di luar maupun di dalam peradilan. D eskripsi dan analisis yang dikemukakan dalam tulisan ini diharapkan dapat memberikan gambaran perkembangan dari proses penyelesaian sengketa ekonomi syariah yang diatur dalam perundang-undangan di Indonesia.

\section{Penyelesaian Sengketa dalam Tradisi Islam}

D alam tradisi Islam telah dikenal cara-cara penyelesaian sengketa sejak lama. Sistem penyelesaian sengketa dalam hukum Islam adalah melalui perdamaian (słalh/lisłlab), melalui arbitrase (tahkim), dan melalui pengadilan kekuasaan kehakiman (wilayat al-cada).

\section{Perdamaian (Stahly ishlab)}

Secara terminologi kata słlih,dimaknai secara beragam oleh para ulama, di antaranya

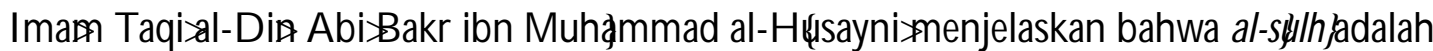
akad yang memutuskan perselisihan dua pihak yang berselisih. ${ }^{3}$ Sementara Sayyid Sabiq berpendapat bahwa al-sklih/merupakan suatu jenis akad untuk mengakhiri perlawanan antara dua orang yang bersengketa. ${ }^{4} \mathrm{D}$ engan mengetengahkan pengertian yang lebih rinci, Hasbi Ash-Shiddiqie menerangkan bahwa al-skllhlyadalah akad yang disepakati dua orang yang bertengkar dalam hak untuk melaksanakan sesuatu, dengan akad itu dapat hilang perselisihan. ${ }^{5}$ D ari pengertian di atas diketahui bahwa dalam perdamaian terdapat dua pihak, yang sebelumnya di antara mereka ada suatu persengketaan, dan kemudian para pihak sepakat untuk saling melepaskan semua atau sebagian dari tuntutannya dengan tujuan mengakhiri persengketaan di antara mereka (pihak yang bersengketa).

Perdamaian dalam syari'ah sangat dianjurkan, sebab dengan adanya perdamaian di antara para pihak yang bersengketa, maka kehancuran silat al-rahim(hubungan kasih sayang) di antara para pihak akan terhindar, dan sekaligus permusuhan di antara mereka akan dapat diakhiri. Tuntutan syari’ah ini termaktub dalam al-Q ur'an surah al-H «ijurat ayat $9^{6}$, surah al-Nisas ayat $114,{ }^{7}$ surah al-Nisas ayat $128 .{ }^{8}$ D ari ketiga ayat ini, al-Q ur'an menekankan agar umat Islam lebih mengedepankan usaha perdamaian ketika terjadi perselisihan atau persengketan baik perselisihan dalam keluarga maupun dalam berhubungan dengan manusia atau masyarakat lainnya. Selain al-Qur'an, Rasulullah saw. juga menganjurkan pelaksanaan perdamaian ini. Salah satu hadis yang diriwayatkan oleh Tirmidhiølari 'Umar ibn 'Awf al-Muzanni>Rasulullah bersabda, yang artinya: "Perdamaian dibolehkan di kalangan kaum muslimin, selain perdamaian yang mengharamkan yang halal atau menghalalkan yang haram. D an orang-orang Islam (yang mengadakan perdamian itu) bergantung pada syarat-syarat mereka (yang telah disepakati), selain syarat yang mengharamkan yang halal atau menghalalkan yang haram." (HR. Tirmidzi)

3Imam Taqiæl-D in A bußakr ibn Muhł̧mmad, Kifayatal-Akhyar(Bandung: al-Ma'arif, t.th.), 271.

${ }^{4}$ Sayyid Sabiq, Fiqhal-Sunnah Juz 3 (Kairo: Dazal-Fath,\}2000), 210.

${ }^{5}$ Hasbie Ash-Ashidiqi, PengantarFiqhMuamalah(Jakarta: Bulan Bintang, 1984), 92.

6al-Q ur'an, 49 (Hujurat): 9.

7al-Q ur'an, 4 (al-Nisa'): 114.

${ }^{8} \mathrm{al}-\mathrm{Q}$ ur'an, 4 (al-Nisa'): 128. 
Hadis ini memberikan penegasan kepada kaum muslimin agar melakukan słlhbdalam menyelesaikan sengketa mereka, kecuali skllh/yang menghalalkan yang haram atau mengharamkan yang halal. Bahkan 'Umar ibn K hattgab mewajibkan hakim pada masanya untuk mengajak para pihak melakukan perdamaian (sklih), baik pada awal proses perkara diajukan kepadanya, maupun pada masa persidangan yang sedang berjalan di pengadilan. Hakim tidak boleh membiarkan para pihak tidak menempuh upaya damai. Hakim harus proaktif dan mendorong para pihak mewujudkan kesepakatan damai dalam sengketa mereka. ${ }^{9}$ Salah satu prinsip yang dibebankan kepada hakim adalah prinsip słllh/kecuali slilh/yang menghalalkan yang haram atau slihlyang mengharamkan yang halal. 'Umar berpandangan bahwa kewajiban ini harus dilakukan hakim, karena melalui upaya damai keadilan dapat diwujudkan bagi para pihak. Putusan mahkamah yang mengikat para pihak tidak dapat memuaskan hati kedua belah pihak, karena putusan tersebut dibuat berdasarkan fakta dan bukti yang telah menempatkan para pihak dalam keadaan menang atau kalah. ${ }^{10}$

Prinsip penerapan s)lih/sebagaimana dianjurkan Rasulullah tersebut baru terjadi bila memenuhi sejumlah rukun dan syaratnya. Para ulama cenderung merumuskan rukun sjlih,dalam dua pandangan yang berbeda. Jumhur ulama berpandangan, rukun skilh/terdiri atas empat unsur, yaitu: adanya kedua belah pihak yang melakukan sklih/ lafal ijab kabul, ada kasus yang dipersengketakan dan adanya bentuk perdamaian yang disepakati oleh kedua belah pihak. Sedangkan mazhab $\mathrm{H}$ \&nafismenyebutkan bahwa rukun słllh/hanyalah ijab dan kabul, selainnya mereka masukkan dalam kategori syarat sjlhy

Secara teknis dalam kasus hukum, tidak semua perkara yang diajukan ke pengadilan dapat diselesaikan melalui jalur skllh ? Perkara atau sengketa yang dapat ditempuh penyelesaiannya melalui jalur skllh/adalah perkara yang di dalamnya mengandung hak manusia (haqqal-ibad) dan bukan perkara yang menyangkut hak Allah (haqqAllab). D alam kategorisasi hukum, perkara atau sengketa yang diajukan upaya damai atau sjlih/adalah perkara yang berkaitan dengan hukum privat, terutama yang berkaitan dengan harta dan keluarga. Sedangkan dalam dimensi publik atau perkara pidana seperti zina, qadhaf, pencurian, minum khamer, dan lain-lain tidak dapat dilakukan upaya damai, karena di sana terdapat hak Allah secara murni. ${ }^{11}$

\section{Arbitrase (Tahkim)}

Al-Tahkim merupakan konsep yang sama dengan arbitrase adalah bagian dari peradilan. Wilayah tahkim adalah wilayah yang didapatkan dari perseorangan. Ini merupakan bagian dari al-cadás yang berhubungan dengan harta benda, bukan dengan alhudud dan al-qis ${ }^{2}$ Para ulama sepakat bahwa para pihak yang bersengketa jika setuju dapat memilih hokamuntuk menyelesaikan sengketa di antara mereka. Ketika persetujuan itu telah diambil, maka apa yang menjadi keputusan dari hakkamitu langsung mengikat tanpa lebih dahulu meminta persetujuan kedua belah pihak. Sedangkan ulama Shafi'iłah

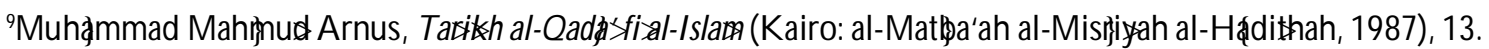

${ }^{10}$ Ibid., 14.

${ }^{11}$ Wahbah al-Zuhłyli;al-Fiqhal-Isami wa Adllatuh Juz 5 (Beirut: D aæal-Fikr, 2003), 295-297. 
berpendapat bahwa putusan hokamsama halnya dengan fatwa yang tidak mengikat kecuali jika ada ketegasan persetujuan dari kedua belah pihak yang bersengketa.

Pada dasarnya putusan hakam itu dilaksanakan atas dasar suka sama suka antara dua orang yang bersengketa. Hakamtidak mempunyai kekuatan untuk memaksa masingmasing pihak yang ternyata di kemudian hari tidak bersedia melaksanakan keputusan itu. Oleh sebab itu, bilamana salah satu pihak tidak bersedia menepati putusan hokkam maka untuk eksekusinya diserahkan kepada pengadilan untuk membantu pelaksanaan putusan itu.

\section{Pengadilan Kekuasaan Kehakiman (Wilayat al-Qada's'}

Al-Q uran dan Hadis Nabi menawarkan proses penyelesaian sengketa di pengadilan melalui dua cara, yaitu pembuktian fakta hukum (adjudikasi), dan penyelesaian melalui perdamaian (isllaky). Penyelesaian sengketa melalui proses pembuktian fakta hukum dilakukan dengan pengajuan sejumlah alat bukti oleh para pihak dalam menuntut atau mempertahankan haknya di hadapan pengadilan. ${ }^{13}$ D alam konteks ini kaidah hukumnya

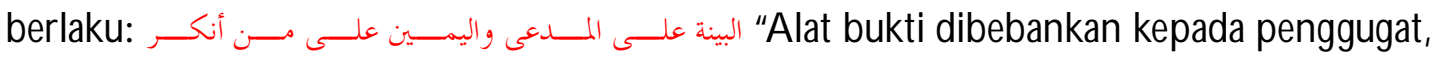
sedangkan sumpah kepada pihak yang mengingkari." ${ }^{14}$ Pengajuan alat-alat bukti ini dimaksudkan untuk membuktikan siapa yang berhak dan berwenang terhadap sesuatu dan siapa yang tidak berwenang atau tidak berhak terhadap sesuatu. Melalui alat bukti akan terungkap dengan jelas duduk perkara dan pihak mana yang mendapat hak sesuai dengan hukum Allah.

Bukti adalah standar ukur (norma) bagi hakim dalam memutuskan perkara. ${ }^{15}$ Siapa yang memiliki bukti yang kuat, maka dialah yang akan memenangkan perkara di pengadilan. Hakim akan memutuskan berdasarkan bukti-bukti kuat yang diajukan para pihak kepadanya. Dalam kenyataannya, pengajuan bukti di pengadilan kadang-kadang juga tidak sesuai dengan fakta yang sebenarnya. Namun, karena para pihak memiliki kemampuan meyakinkan hakim dengan alat bukti yang diajukan, maka hakim akan memutuskan perkara berdasarkan bukti itu. Hakim tidak tahu hakikat yang sebenarnya dari alat bukti yang diajukan kepadanya, apakah alat bukti tersebut sesuai dengan fakta yang sebenarnya atau tidak. A lat bukti palsu dan kesaksian palsu yang disebutkan Alquran sebagai pertanda bahwa dalam praktik penyelesaian perkara di pengadilan sangat terbuka lebar. Karena itu Allah mengingatkan: "janganlah kamu membalikkan kata-kata" dalam memberikan kesaksian di pengadilan, karena Allah Maha Mengetahui apa yang kamu kerjakan.

Proses penyelesaian sengketa melalui adjudikasi ternyata tidak mampu menyelami hakikat fakta sebenarnya dari persengketaan para pihak, karena hakim hanya mampu memahami dan memutuskan perkara sebatas alat bukti kuat yang diajukan kepadanya. Atas dasar keyakinan hakim dan bukti-bukti yang ada, maka ia memutuskan hukum tersebut, padahal hakikatnya yang paling tahu adalah para pihak yang bersengketa. Jadi,

\footnotetext{
${ }^{12}$ Wirdyaningsih et al., Bank danAsurans Idamdi Indonesia(Jakarta: Prenada Media G roup, 2005), 231.

${ }^{13}$ A bdul Rahim, thePriniples MuhammadanJunispudane(London: Luzac \& Co, 1991), 366-367.

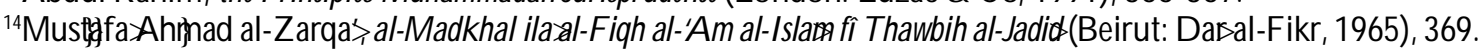

${ }^{15} \mathrm{~A}$ bdul Rahim, thePrinaples Muhammadan 368.
} 
penyelesaian melalui adjudikasi tidak dapat menjamin kepuasan para pihak yang bersengketa, karena ada pihak yang memiliki keterbatasan dalam pengajuan alat bukti. Oleh karenanya, sejumlah ayat Alquran lebih mengutamakan penyelesaian sengketa melalui perdamaian di hadapan hakim.

\section{Penyelesaian Sengketa dalam Tata Hukum Indonesia}

Secara prinsip, penegakan hukum hanya dilakukan oleh kekuasaan kehakiman (judiaal power) yang dilembagakan secara konstitusional yang lazim disebut badan yudikatif (Pasal 24 UUD 1945). D engan demikian, yang berwenang memeriksa dan mengadili sengketa hanya badan peradilan yang bernaung di bawah kekuasaan kehakiman yang berpuncak di Mahkamah Agung Republik Indonesia.

Pasal 2 UU No. 14 tahun 1970 dengan tegas juga memperingatkan bahwa yang berwenang dan berfungsi melaksanakan peradilan hanya badan-badan peradilan yang dibentuk berdasarkan undang-undang. Di luar itu tidak dibenarkan karena tidak memenuhi syarat formal dan official dan bertentangan dengan prinsip under the authority of law Namun, berdasarkan Pasal 1851, 1855, 1858 KUH Perdata Penjelasan Pasal 3 UU NO. 14 tahun 1970 serta UU No. 30/ 1999 tentang Arbitrase dan Alternatif Penyelesaian Sengketa, maka terbuka kemungkinan para pihak menyelesaikan sengketa dengan menggunakan lembaga selain pengadilan, seperti arbitrase atau perdamaian (isłab).

Secara filosofis, juridis dan sosiologis yang melatarbelakangi ditetapkannya UndangUndang Nomor 30 Tahun 1999 tentang Arbitrase dan Alternatif Penyelesaian Sengketadiundangkan pada tanggal 12 Agustus 1999-ini pada dasarnya dapat ditelusuri dari keterangan pemerintah di hadapan Rapat Paripurna D ewan Perwakilan Rakyat Republik Indonesia mengenai Rancangan Undang-Undang ini pada tanggal 14 Maret 1999. Pemerintah menyatakan bahwa perkembangan dunia usaha dan perkembangan lalu lintas di bidang perdagangan baik nasional maupun internasional menunjukkan intensitasnya, sekalipun di beberapa belahan bumi sedang dilanda berbagai krisis moneter. ${ }^{16}$ Sebagai konsekuensi dari kegiatan perdagangan yang semakin pesat tersebut, tidak menutup kemungkinan timbulnya berbagai konflik dan sengketa di antara berbagai pihak. Pihak yang bersengketa ini memerlukan penyelesaian sengketa dengan cepat dan tepat, karenanya perlu dibuka kemungkinan adanya lembaga di luar pengadilan yang dapat memberikan jasa sebagai media dalam penyelesaian sengketa tersebut. Penyelesaian sengketa di luar pengadilan merupakan salah satu solusi, yakni melalui arbitrase dan alternatif penyelesaian sengketa yang kemudian diatur dalam Undang-Undang Nomor 30 tahun 1999.

Penyelesaian sengketa khususnya sengketa perdata dalam Tata Hukum Indonesia pada dasarnya dapat digolongkan menjadi dua, yaitu penyelesaian sengketa melalui pengadilan (litigasi) dan penyelesaian sengketa di luar pengadilan (non litigasi). Namun, kenyataan menunjukkan bahwa penyelesaian melalui pengadilan selalu dihindari banyak orang dikarenakan proses dan jangka waktu penyelesaiannya yang relatif lama dan berlarut-larut,

${ }^{16}$ Sudargo Gautama, UndangUndangArlitraseBaru(Bandung: PT. Citra Adtya Bakti, 1999), 312. Lihat juga Syuaibun, "Alternatif Penyelesaian Sengketa dalam Perspektif Undang-Undang Nomor 30 Tahun 1999," Istisah:Jurnal HukumIsam Vol. 3, No. 1 (Januari-Juni 2004), 64. 
serta oknum-oknum di lembaga peradilan tersebut dianggap cendrung "mempersulit" proses pencarian keadilan. Akhirnya, banyak pihak mencoba menghindari penyelesaian sengketa yang dihadapi melalui peradilan ini dan menempuh proses di luar lembaga Pengadilan. ${ }^{17}$

UU Nomor 30 tahun 1999 menjelaskan bahwa institusi penyelesaian sengketa di luar pengadilan dapat dilakukan dengan beberapa cara, yaitu:

\section{Arbitrase}

Pasal 1 ayat (1) UU Nomor 30 tahun 1999 menyatakan bahwa cara penyelesaian suatu sengketa perdata di luar pengadilan umum didasarkan kepada perjanjian arbitrase yang dibuat tertulis oleh para pihak yang bersengketa. Dari pasal ini dapat dipahami bahwa arbitrase sebagai suatu cara penyelesaian sengketa keperdataan hanya dapat dilakukan apabila perkara tersebut menjadi kewenangan pengadilan umum bukan kewenangan pengadilan lainnya sebagaimana ditentukan dalam UU Nomor 14 tahun 1870 tentang Ketentuan-ketentuan Pokok Kekuasaan Kehakiman. Dalam hal sengketa keperdataan dibatasi dalam bidang perdagangan dan mengenai hak yang menurut hukum dan peraturan perundang-undangan dikuasai sepenuhnya oleh pihak yang bersengketa.

Paling tidak ada beberapa alasan yang dapat dikemukakan mengapa arbitrase dijadikan salah satu alternatif penyelesaian sengketa perdata. D alam penjelasan UU Nomor 30 tahun 1999 disebutkan beberapa kelebihan lembaga arbitrase dibandingkan dengan lembaga peradilan dalam menyelesaikan suatu sengketa, yaitu: a) dijamin kerahasiaan sengketa para pihak, b) dapat dihindari kelambatan yang diakibatkan karena hal prosedural dan administratif, c) para pihak dapat memilih arbiter yang menurut keyakinannya mempunyai pengetahuan, pengalaman serta latar belakang yang cukup mengenai masalah yang disengketakan, jujur dan adil, d) para pihak dapat memilih hukum apa yang akan diterapkan untuk menyelesaikan masalahnya serta proses dan tempat penyelenggaraan arbitrase, dan e) putusan arbiter merupakan putusan yang mengikat para pihak dengan melalu tata cara (prosedur) sederhana saja ataupun langsung dilaksanakan.

2. Konsultasi, Negosiasi, Mediasi, Konsiliasi atau Penilaian Ahli

Beberapa alternatif penyelesaian pada poin 2 ini muncul bukan tanpa dasar tetapi lebih didasarkan pada pada Pasal 1 ayat (10) UU Nomor 30 tahun 1999, yaitu: petama, konsultasi, yaitu alternatif penyelesaian sengketa adalah lembaga penyelesaian sengketa atau beda pendapat melalui prosedur yang disepakati para pihak, yakni penyelesaian di luar pengadilan dengan cara konsultasi, negosiasi, mediasi, konsiliasi atau penilaian ahli. UU Nomor 30 tahun 1999 tidak menegaskan suatu rumusan atau penjelasan tentang konsultasi. D alam realitas sosial istilah konsultasi sering dimaknakan tindakan yang bersifat personal antara satu pihak tertentu yang biasanya disebut klien dengan pihak lain yang disebut konsultan untuk dijadikan mitra dalam membahas persoalan yang dihadapi. Sebagai mitra pihak konsultan memberi pendapat dan masukan kepada kliennya untuk mengatasi persoalan yang dihadapinya. D alam pemahaman ini dapat dinyatakan bahwa pihak yang melakukan konsultasi (klien) tidak memiliki keterikatan atau kewajiban secara hukum untuk memenuhi dan mengikuti pendapat yang disampaikan oleh konsultan.

\footnotetext{
${ }^{17}$ Syuaibun, "Alternatif Penyelesaian Sengketa,", 62.
} 
Hal ini berarti peran konsultan tidak dominan, sebab keputusan tetap berada pada para pihak yang bersengketa. Konsultan hanya menyampaikan pendapatnya sebagaimana yang diminta oleh kliennya.

Keda, negoisasi. Adapun negoisasi pada dasarnya diartikan sebagai suatu proses tawar-menawar atau pembicaraan langsung untuk mencapai suatu kesepakatan terhadap masalah tertentu yang terjadi di antara para pihak. Ketentuan tentang negoisasi sebagai institusi hukum yang dapat menyelesaikan sengketa ditegaskan dalam pasal 6 ayat (2): "Penyelesaian sengketa atau beda pendapat melalui alternatif penyelesaian sengketa sebagaimana dimaksud dalam ayat (1) diselesaikan dalam pertemuan langsung oleh para pihak dalam waktu paling lama 14 (empat belas) hari dan hasilnya dituangkan dalam kesepakatan tertulis."

Ketiga, mediasi. Ketika jalur negoisasi gagal ditempuh, maka pihak yang bersengketa dapat menempuh proses mediasi. Mediasi merupakan proses penyelesaian sengketa melalui pihak luar yang tidak memihak dan bekerjasama dengan pihak yang bersengketa untuk membantu menemukan solusi dalam menyelesaikan sengketa secara memuaskan bagi para pihak yang bersengketa. Isyarat mediasi sebagai lanjutan dari gagalnya negoisasi dijelaskan pada pasal 6 ayat (3) yang mengemukakan dalam hal sengketa atau beda pendapat sebagaimana dimaksud dalam ayat (2) tidak dapat diselesaikan, maka atas kesepakatan melalui bantuan seorang atau lebih penasehat ahli maupun melalui mediator.

Mediator sebagaimana yang dijelaskan di atas, jelas melibatkan pihak ketiga yang bersifat netral dan tidak memihak berkewajiban untuk melaksanakan tugas dan fungsinya berdasarkan pada kehendak dan kemauan para pihak yang bersengketa. Ia tidak berwenang memaksa, melainkan ia hanya berkewajiban bertemu atau mempertemukan para pihak yang bersengketa guna mencari masukan mengenai pokok-pokok persoalan yang dipersengketakan. Berdasarkan informasi yang diperolehnya, maka mediator mencoba menyusun proposal penyelesaian dan kemudian dikonfirmasikan kepada para pihak secara langsung.

Mediator harus mampu menciptakan suasana dan kondisi yang kondusif bagi terciptanya kompromi di antara para pihak yang bersengketa untuk memperoleh hasil yang saling menguntungkan. Setelah diperoleh persetujuan dari para pihak atas proposal yang diajukan mediator tersebut untuk menyelesaikan masalah yang mereka persengketakan, maka mediator kemudian menyusun kesepakatan itu secara tertulis untuk kemudian ditandatangani kedua belah pihak. ${ }^{18}$

Kesepakatan tertulis yang telah dibuat tersebut menjadi kesepakatan final dan mengikat untuk dilaksanakan dengan itikad baik oleh para pihak yang bersengketa. Kemudian kesepakatan tertulis tersebut wajib didaftarkan di Pengadilan Negeri dalam waktu paling lama 30 (tiga puluh) hari terhitung serjak penandatanganan, dan wajib dilaksanakan dalam waktu paling lama 30 (tiga puluh) hari sejak pendaftaran. Hal ini tertuang dalam pasal 6 ayat (6) yang menyatakan bahwa usaha penyelesaian sengketa atau beda pendapat melalui mediator sebagaimana dimaksud dalam ayat (5) dengan memegang teguh kerahasiaan dalam waktu paling lama 30 (tiga puluh) hari harus dicapai

\footnotetext{
${ }^{18} \mathrm{G}$ unawan Widjaja dan A hmad Yani, Sei Hukum 34.
} 
kesepakatan dalam bentuk tertulis yang ditandatangani semua pihak yang terkait. Kemudian dalam ayat (8) disebutkan pula bahwa kesepakatan penyelesaian sengketa atau beda pendapat sebagaimana dimaksud dalam ayat (7) wajib dilaksanakan dalam waktu paling lama 30 (tiga puluh) haru sejak pendaftaran.

Keempat, konsiliasi. UU Nomor 30 tahun 1999 tidak memberikan suatu rumusan eksplisit atau definisi yang jelas tentang konsiliasi. Namun berdasarkan pemahaman terhadap penjelasan undang-undang tersebut dapat dinyatakan bahwa konsiliasi merupakan salah satu proses penyelesaian sengketa perdata yang disepakati para pihak untuk dilakukan di luar pengadilan dengan melibatkan pihak ketiga yang netral dan tidak memihak.

D alam hal peranannya antara mediator dan konsiliator terdapat perbedaan sekalipun antara keduanya dalam hal-hal tertentu terdapat kesamaan. Sebagaimana halnya dengan seorang mediator, tugas dari konsilitor hanya sebagai pihak fasilitator untuk melakukan komunikasi diantara para pihak sehingga dapat ditemukan solusi oleh para pihak itu sendiri. Secara lebih tegas dikemukakan oleh Munir Fuady bahwa pihak konsiliator hanya melakukan tindakan-tindakan seperti mengatur waktu dan tempat pertemuan para pihak, mengarahkan subjek pembicaraan, membawa pesan dari satu pihak kepada pihak lain jika pesan tersebut tidak mungkin disampaikan atau tidak mau bertemu muka langsung dan lain-lain. ${ }^{19}$ Sekalipun pihak konsiliator melakukan hal-hal yang dilakukan seorang mediator namun pihak konsiliator sama-sama tidak berwenang memutus perkara. D alam pemahaman lain dapat dinyatakan keputusan dan persetujuan terhadap keputusan perkara tetap berada di tangan pihak yang bersengketa.

Keima, pendapat ahli. Berdasarkan isyarat pasal 1 ayat (10) UU Nomor 30 tahun 1999 menyatakan bahwa pendapat ahli merupakan salah satu institusi penyelesaian sengketa di luar pengadilan. Namun sebagaimana halnya dengan institusi-institusi lainnya selain arbitrase, undang-undang tersebut tidak dengan tegas dan jelas memberikan pengertian dan juga mekanisme tentang pendapat ahli tersebut.

Yang dimaksud dengan pendapat ahli adalah pendapat hukum dari ahli hukum baik secara personal maupun kelembagaan. Tujuan dicantumkannya pendapat para ahli tersebut sebagai alternative penyelesaian sengketa adalah untuk masukan para pihak dalam menyusun atau membuat suatu perjanjian yang akan mengatur hak-hak dan kewajiban masing-masing pihak, bahkan para ahli hokum dapat diminta pendapatnya tentang interpretasi atau penjelasan suatu perjanjian yang telah dibuat para pihak. Pemahaman ini hampir dapat disamakan dengan konsultasi, yang berarti penyelesaian sengketa melalui pendapat ahli tidaklah dominan, namun sebatas memberi pendapat hukum sedang yang mengambil keputusan tetap para pihak yang bersengketa.

\section{Penyelesaian Sengketa Lembaga Keuangan Syariah}

Penyelesaian sengketa di Lembaga Keuangan Syari'ah setidaknya sudah diatur dalam tiga peraturan perundang-undangan, yaitu UU No. 21 tahun 2008 tentang Perbankan Syari'ah, ${ }^{20}$ UU No. 3 tahun 2006 tentang Peradilan Agama, ${ }^{21}$ dan PBI No. 9/ 19/ PBI/ 2007

${ }^{19}$ Munir Fuady, ArditraseNasional (Bandung: PT. Citra Aditya, 2000), 52.

${ }^{20}$ Pasal-pasal dalam UU No. 21 Tahun 2008 tentang Perbankan Syariah dikutip dari RUU Perbankan Syariah yang disahkan oleh D PR, 17 Juni 2008, yang dikeluarkan oleh Sekretaris Jenderal D PR RI, 17 Juni 2008 serta Lembaran 
tentang Pelaksanaan Prinsip Syariah dalam Kegiatan Penghimpunan D ana dan Penyaluran serta Pelayanan Jasa Bank Syariah. ${ }^{22}$

Pasal 49 UU No. 3 Tahun 2006 tentang Peradilan Agama menjelaskan bahwa Pengadilan Agama bertugas dan berwenang memeriksa, memutus, dan menyelesaikan perkara di tingkat pertama antara orang-orang yang beragama Islam di bidang: a) perkawinan, b) waris, c) wasiat, d) hibah, e) wakaf, f) zakat, g) infaq, h) sedekah, dan i) ekonomi syariah. Penjelasan Pasal 49 huruf h "ekonomi syariah" adalah perbuatan atau kegiatan usaha yang dilaksanakan menurut prinsip syariah, antara lain meliputi: a) bank syariah, b) lembaga keuangan mikro syariah, c) asuransi syariah, d) reasuransi syariah, e) reksadana syariah, f) obligasi syariah dan surat berharga berjangka menengah syariah, g) sekuritas syariah, h) pembiayaan syariah, i) pegadaian syariah, j) dana pensiun lembaga keuanan syariah, dan k) bisnis syariah.

Selain itu, penjelasan Pasal 49 UU No. 3 tahun 2006 menyebutkan bahwa yang dimaksud dengan "antara orang-orang yang beragama Islam" adalah termasuk orang atau badan hukum yang dengan sendirinya menundukkan diri dengan sukarela kepada hukum Islam mengenai hal-hal yang menjadi kewenangan Peradilan Agama sesuai dengan ketentuan pasal ini. Dikaitkan dengan asas personalitas keislaman, hal ini berarti seorang non muslim yang melakukan transaksi pada suatu Lembaga Ekonomi Syariah berarti ia telah menundukkan diri secara sukarela pada ketentuan hukum Islam. Misalnya, apabila terjadi suatu transaksi oleh nasabah nonmuslim di suatu bank Islam, maka hubungan hukum yang terjadi antara nasabah tersebut dengan bank Islam adalah berdasarkan hukum Islam. Sehingga apabila terjadi suatu sengketa, maka harus diselesaikan menurut hukum Islam, yaitu dapat melalui iskaby(musyawarah), Basyarnas, atau ke Pengadilan Agama.

Asas penundukan diri sebagai salah satu asas yang menyebutkan bahwa kalau seseorang telah bersedia dengan sesuatu, maka dia harus bersedia menerima segala konsekuensi dari

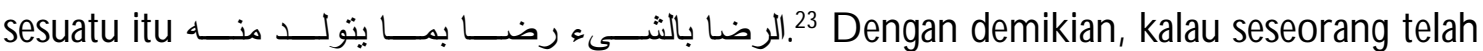
bersedia melakukan perikatan yang didasarkan kepada ekonomi syariah, maka dia harus menerima sengketanya dalam ekonomi syariah diselesaikan dengan sistem penyelesaian sengketa menurut peradilan yang menetapkan hukum Islam. Oleh karena penyelesaian sengketa dengan sistem yang Islami hanya ada di Peradilan Agama, maka orang yang berhubungan dengan perikatan yang didasarkan keapda sistem ekonomi Islam/ syariah juga penyelesaian sengketanya dalah di Pengadilan Agama.

Pasal 55 UU No. 21 tahun 2008 tentang Perbankan Syariah menjelaskan bahwa penyelesaian sengketa terkait Perbankan Syariah dapat dilakukan melalui dua jalur pengadilan, yaitu: 1) dilakukan oleh pengadilan agama dalam lingkungan peradilan agama, dan 2) di luar pengadilan agama dalam hal para pihak telah memperjanjikan melalui akad penyelesaian sengketa selain melalui pengadilan agama, dengan catatan penyelesaian sengketa tadi tidak

Negara Republik Indonesia tahun 2008 No. 94 dan Tambahan Lembaran Negara Nomor 4867.

${ }^{21}$ UU No. 3 Tahun 2006 tentang Peradilan Agama dimuat dalam Lembaran Negara Tahun 2006 No. 22 dan Tambahan Lembaran Negara No. 4611.

${ }_{22}^{22 B I}$ No. 9/ 19/ PBI/ 2007 tentang Pelaksanaan Prinsip Syariah dalam Kegiatan Penghimpunan Dana dan Penyaluran serta Pelayanan Jasa Bank Syariah dikutip dari Lembaran NegaraTahun 2007 No. 165.

${ }^{23}$ Lihat Jalabal-D in al-Suyutisal-A shbahwaal-Nazä́lirfi al-Funu'(Jakarta: as-Fakofah al-Islamiyah, t.th.), 97. 
boleh bertentangan dengan prinsip syariah. Yang dimaksud dengan "penyelesaian sengketa dilakukan di luar pengadilan agama sesuai dengan isi akad" adalah upaya sebagai berikut: a) musyawarah, b) mediasi perbankan, c) melalui Badan Arbitrase Syariah Nasional (Basyarnas) atau lembaga arbitrase lain, dan/ atau d) melalui pengadilan dalam lingkungan peradilan umum.

Sedangkan Pasal 4 PBI No. 9/ 19/ PBI/ 2007 tentang Pelaksanaan Prinsip Syariah dalam Kegiatan Penghimpunan D ana dan Penyaluran serta Pelayanan Jasa Bank Syariah menjelaskan bahwa penyelesaian sengketa antara bank dan nasabah dilakukan secara musyawarah. Jika musyawarah tidak mencapai kesepakatan, maka penyelesaian sengketa dilakukan melalui mediasi, termasuk mediasi perbankan. Jika mediasi tidak mencapai kesepakatan, maka penyelesaian dilakukan melalui mekanisme arbitrase syariah atau melalui lembaga peradilan yang ditentukan peraturan perundang-undangan yang berlaku (Pasal 4 ayat 1-2 PBI No. 9/ 19/ PBI/ 2007). Sebagai catatan, PBI No. 9/ 19/ PBI/ 2007 menyebut istilah bank sebagai ganti dari istilah Bank Umum Syariah (BUS), Unit Usaha Syariah (UUS), dan Bank Pembiayaan Rakyat Syariah (BPRS).

1. Penyelesaian melalui Perdamaian

Sudah menjadi asas dalam hukum acara perdata bahwa pengadilan (hakim) wajib mendamaikan pihak beperkara. A sas ini mengharuskan pengadilan (hakim) agar dalam menangani suatu perkara perdata yang diajukan kepadanya terlebih dahulu berupaya mendamaikan kedua belah pihak beperkara. Kelalaian hakim mengupayakan perdamaian bagi kedua belah pihak beperkara akan mengakibatkan batalnya pemeriksaan perkara tersebut demi hukum. ${ }^{24}$

Terkait dengan upaya damai yang harus dilakukan hakim dalam rangka menyelesaikan perkara-perkara di bidang ekonomi syariah umumnya dan bidang perbankan syariah khususnya di lingkungan peradilan agama, paling tidak ada dua ketentuan yang harus diperhatikan yaitu: ketentuan Pasal 154 R.Bg/ 130 HIR dan Peraturan Mahkamah Agung (PERMA) No. 01 Tahun 2008 tentang Prosedur Mediasi di Pengadilan. Ketentuan Pasal 154 R.Bg/ 130 HIR dan Peraturan Mahkamah Agung (PERMA) No. 01 Tahun 2008 tidak lain merupakan landasan yuridis dalam mengupayakan perdamian di pengadilan tingkat pertama termasuk di lingkungan peradilan agama yang harus dipahami dan diterapkan sebagaimana mestinya.

Jika ketentuan Pasal 154 R.Bg/ 130 HIR hanya mengisyaratkan bahwa upaya damai yang dilakukan hakim hanya bersifat anjuran, bahkan dikatakan bercorak formalitas dan regulatif serta sukarela, tidak bersifat memaksa, ${ }^{25}$ maka dalam PERMA No. 01 Tahun 2008 tidak lagi hanya sebatas anjuran atau imbauan yang bersifat formalitas saja, melainkan sudah bersifat memaksa. D engan demikian, setelah diterbitkannya PERMA tersebut dalam upaya mendamaikan pihak yang beperkara, baik hakim yang menangani perkara bersangkutan maupun para pihak dalam perkara tersebut sama sekali tidak punya pilihan. Hakim wajib terlebih dahulu memerintahkan para pihak untuk menempuh proses mediasi. Sedangkan para pihak wajib terlebih dahulu melaksanakan apa yang diperintahkan

\footnotetext{
${ }^{24}$ M. Yahya Harahap, HukumA caraPedata(Jakarta: Sinar G rafika, 2005), 239.

25Ibid., 250.
} 
hakim tersebut.

\section{a. Upaya Damai mdalui Musyamarah}

Seperti telah dikemukakan sebelumnya bahwa sebelum menempuh jalur pengadilan, hakim dapat mengupayakan perdamaian terlebih dahulu di antara pihakpihak yang beperkara tanpa melalui pihak ketiga tetapi melalui musyawarah. Tindakan perdamaian ini juga diatur dalam Pasal 154 R.Bg/ 130 HIR, yang berbunyi: 1) bila pada hari yang telah ditentukan para pihak datang menghadap, maka pengadilan negeri dengan perantaraan ketua berusaha mendamaikannya, dan 2) bila dapat dicapai perdamaian, maka di dalam sidang itu juga dibuatkan suatu akta dan para pihak dihukum untuk mentaati perjanjian yang telah dibuat, dan akta itu mempunyai kekuatan serta dilaksanakan seperti suatu surat keputusan biasa.

D ari ketentuan pasal tersebut secara garis besar dapat dipahami bahwa tindakan yang pertama-tama harus dilakukan hakim dalam upaya mendamaikan pihak beperkara adalah berusaha menganjurkan atau mendorong para pihak yang bersengketa agar mereka secara sukarela menyelesaikan sendiri perkaranya secara damai, tanpa keterlibatan hakim atau pihak mana pun di dalamnya. Kemudian apabila tercapai kesepakatan antara kedua belah pihak untuk menyelesaikan perkaranya secara damai, maka kesepakatan itu dituangkan dalam bentuk perjanjian (akta) perdamaian yang ditandatangani oleh para pihak itu sendiri. D engan demikian tindakan yang lebih dahulu harus dilakukan hakim dalam mengupayakan perdamian bagi kedua belah pihak di persidangan dalam perkara perbankan syariah sesuai dengan ketentuan Pasal 154 R.Bg/ 130 HIR. $^{26}$

\section{b. Upaya Damai mdalui Medias}

Mediasi yang diterapkan dalam sistem peradilan menurut ketentuan Pasal 1 butir 7 PERMA diartikan "cara penyelesaian sengketa melalui proses perundingan untuk memperoleh kesepakatan para pihak dengan dibantu oleh mediator." Dari ketentuan tersebut dapat dipahami bahwa mediasi yang dimaksud di sini adalah a) penyelesaian sengketa melalui proses perundingan antar para pihak, dan b) perundingan para pihak tersebut dibantu oleh mediator.

Penjelasan mediasi dari perspektif PERMA di atas menunjukkan pada peran pihak ketiga yang menjembatani para pihak bersengketa untuk menyelesaikan perselisihan. Penjelasan ini amat penting guna membedakan dengan bentuk-bentuk alternative penyelesaian sengketa lainnya seperti arbitrase, negosiasi, adjudikasi dan lain-lain. Mediator berada pada posisi di 'tengah dan netral' antara para pihak yang bersengketa, dan mengupayakan menemukan sejumlah kesepakatan sehingga mencapai hasil yang memuaskan para pihak yang bersengketa. ${ }^{27}$ Jadi, kedudukan dan fungsi mediator dalam proses perundingan tersebut menurut Pasal 1 butir 6 PERMA adalah sebagai pihak yang netral (tidak memihak) yang akan membantu para pihak dalam

\footnotetext{
${ }^{26}$ Cik Basir, Penydesaian Sengkła Pedbankan Syariahd PengadilanAgama \& Mahkamah Syaniah(Jakarta: Kencana, 2009), 131-132.

${ }^{27}$ Penjelasan lengkap mengenai mediasi dapat dilihat dalam Syahrizal Abbas, Meedias dalamPerspaktif Hukum Syariah, HukumAdatdan HukumNasional, ed. A gustina Arida dan Luthfi Aunie (Jakarta: Prenada Media G roup, 2009).
} 
proses perundingan guna mencari berbagai kemungkinan penyelesaian sengketa tanpa menggunakan cara memutus atau memaksakan sebuah penyelesaian tertentu.

D ari sini terlihat jelas perbedaan antara upaya damai melalui mediasi dengan upaya damai musyawarah yang diatur dalam Pasal 154 R.Bg/ 130 HIR. D alam upaya damai melalui mediasi, mediator senantiasa terlibat langsung secara aktif dalam setiap pertemuan selama proses perundingan antarpara pihak dalam upaya menyelesaikan sengketa tersebut. Tidak demikian halnya dengan upaya damai yang dilakukan atas dasar ketentuan Pasal 154 R.Bg/ 130 HIR, di mana hakim hanya diberi kewenangan secara formalitas, sebatas menganjurkan apra pihak untuk menyelesaikan sendiri perkaranya secara damai tanpa adanya keterlibatan pihak mana pun di dalamnya.

D alam PERMA ini juga telah diatur siapa saja yang dapat bertindak sebagai mediator. Pasal 8 ayat (1) dikemukakan bahwa orang yang bertindak dan diperkenankan dipilih oleh para pihak untuk menjadi mediator adalah a) hakim bukan pemeriksa perkara pada pengadilan yang bersangkutan, b) advokat atau akademisi hukum, dan c) profesi bukan hukum yang dianggap para pihak menguasai atau berpengalaman dalam pokok sengketa.

\section{c. Arditrase Penydesaian di Luar Pengadilan Agama}

Upaya penyelesian di luar pengadilan dilakukan melalui lembaga arbitrase setelah tidak berhasil diselesaikan melalui lembaga musyawarah dan mediasi. Berkenaan dengan lembaga arbitrase ini, bank syariah pada awalnya membentuk lembaga arbitrase syariah yang kemudian dikenal dengan Badan Arbitrase Mu'amalat Indonesia (BAMUI) yang sekarang berganti nama dengan Badan Arbitrase Syariah Nasional (Basyarnas). ${ }^{28}$

Abdulkadir Muhammad menyatakan bahwa arbitrase adalah badan peradilan swasta di luar lingkungan Peradilan Umum (untuk sengketa ekonomi syariah Peradilan Agama) yang dikenal khusus dalam perusahaan. Arbitrase adalah peradilan yang dipilih dan tentukan sendiri secara sukarela oleh pihak-pihak pengusaha yang bersengketa. Penyelesaian sengketa di luar pengadilan merupakan kehendak bebas dari para pihak. Kehendak bebas ini dapat dituangkan dalam perjanjian tertulis yang mereka buat sebelum atau sesudah terjadi sengketa sesuai dengan asas kebebasan berkontrak dalam hukum perdata. ${ }^{29}$

D engan demikian, perjanjian arbitrase timbul karena adanya kesepakatan secara tertulis dari para pihak untuk menyerahkan penyelesaian suatu sengketa kepada lembaga arbitrase. D engan adanya kesepakatan tertulis tadi, berarti meniadakan hak para pihak untuk mengajukan penyelesaian sengketa ke Pengadilan. Selanjutnya Pengadilan wajib menolak dan tidak akan campur tangan dalam menyelesaikan sengketa yang sudah ditetapkan melalui arbitrase.

Telah diterangkan sebelumnya bahwa kewenangan absolute lingkungan peradilan agama tidak menjangkau sengketa atau perkara perjanjian yang di dalamnya terdapat klausula arbitrase. Oleh karena itu, hakim dituntut untuk memperhatikan dan

\footnotetext{
${ }^{28}$ Mengenai lembaga Arbitrase ini lihat A. Rahmadi Rosyadi dan Ngatino, ArbitrasedalamPerspaktif Isamdan HukumPositif(Bandung: Citra Aditya Bakti, 2002).

${ }^{29}$ A bdulkadir Muhammad, Pengantar HukumPerusahaanIndonesia(Bandung: PT. Citra Bakti, 1993), 276.
} 
memastikan terlebih dahulu ketentuan akad perjanjian sebelum proses pemeriksaan perkara tersebut berjalan lebih jauh. Bahkan seharusnya, hakim melaksanakan ini sebelum mengupayakan perdamaian bagi para pihak. Jika perkara tersebut ternyata merupakan sengketa perjanjian yang mengandung klausula artibrase, maka tidak perlu lagi hakim melanjutkannya dan mengupayakan perdamaian karenajelas perkara tersebut tidak termasuk wewenang absolute lingkungan peradilan agama. ${ }^{30}$

Penyelesaian melalui lembaga A rbitrase merupakan pilihan terbaik yang ditempuh sebelum proses lembaga peradilan. Mariam D arus Badrulzaman menjelaskan beberapa alasan atas pilihan ini, yaitu: a) kepercayaan dan keamanan. Pada arbitrase, para pihak yang bersengketa diberikan kebebasan dan otonomi yang sangat luas. Mereka juga merasa aman terhadap keadaan yang tidak menentu dan ketidakpastian sehubungan dengan sistem hukum yang berbeda, b) keahlian (expertise). Para arbiter adalah orangorang yang memiliki keahlian mengenai hal yang disengketakan. Para pihak yang bersengketa pun dapat menunjuk arbiter untuk menyelesaikan sengketanya, c) cepat dan hemat biaya. Proses penyelesaian sengketa di arbitrase sering kali lebih cepat, tidak terlalu formal dan lebih murah daripada di pengadilan. ${ }^{31}$ Selain itu juga tidak ada kemungkinan kasasi terhadap keputusan arbitrase.

Selain memiliki kelebihan, arbitrase tentu juga memiliki kelemahan, di antaranya: petama, hanya untuk para pihak bona fide Arbitrase hanya bermanfaat untuk para pihak atau pengusaha yang bona fide atau jujur dan dapat dipercaya. Para pihak yang bonafid adalah mereka yang memiliki kredibilitas dan integritas, artinya patuh terhadap kesepakatan, pihak yang dikalahkan harus secara sukarela melaksanakan putusan arbitrase. Sebaliknya, jika ia selalu mencari-cari peluang untuk menolak melaksanakan putusan arbitrase, perkara melalui arbitrase justru akan memakan lebih banyak biaya, bahkan lebih lama daripada proses di pengadilan. Misalnya, pengusaha yang dikalahkan tidak setuju dengan suatu putusan arbitrase, maka ia dapat melakukan berbagai cara untuk mendapatkan stay of exeation (penundaan pelaksanaan putusan) dengan membawa perkaranya ke pengadilan. D emikian pula tidak jarang ditemui di dalam praktik bahwa para pihak, walaupun mereka telah memuat klausul arbitrase dalam perjanjian bisnisnya, tetap saja mereka mengajukan perkaranya ke pengadilan.

Kedua, ketergantungan mutlak para arbiter. Keputusan arbitrase selalu tergantung pada kemampuan teknis arbiter dalam memberikan putusan yang memuaskan dan

\footnotetext{
${ }^{30}$ Cik Basir, Penydesaian Sengkea, 145-146.

${ }^{31}$ Proses penyelesaian sengketa lebih cepat karena didukung oleh beberapa sifat yang melekat badan arbitrase, yaitu; petama, bersifat rahasia, yaitu Proses penyelesaian sengketa yang dilakukan di arbitrase bersifat tertutup untuk melindungi para pihak dari hal-hal yang tidak diinginkan atau yang merugikan akibat penyingkapan informasi bisnis kepada umum, keelua, bersifat nonpreseden, Keputusan arbitrase terdahulu tidak dapat memengaruhi keputusan arbitrase yang akan diputuskan (nonpreseden). Sehingga dimungkinkan untuk perkara yang serupa dihasilkan keputusan arbitrase yang berbeda, keiga, Kepekaan arbiter, kepekaan atau kearifan dari arbiter terhadap perangkat aturan yang akan diterapkan oleh arbiter pada perkara-perkara yang ditanganinya, dan kempet, Keputusan arbitrase bersifat final, sehingga mungkin akan lebih mudah dilaksanakan daripada keputusan pengadilan. Lihat Mariam D arus Badrulzaman, "Peranan BAMUI dalam Pembangunan Hukum Nasional," dalam Abdul Rahman Saleh, et al., ArditraseIdamIndonesia(Jakarta: BAMUI kerjasama dengan Bank Muamalat, 1994), h. 58-60. Untuk penjelasan yang sama lihat Eman Suparman, Pilihan FonumArbitrasedalamSengkea Konersial untuk Penegkan Keadlan(Jakarta: PT. Tatanusa, 2004), 76-79.
} 
sesuai dengan rasa keadilan para pihak. Meskipun arbiter memiliki keahlian teknis yang tinggi, bukanlah hal yang mudah bagi majelis arbitrase untuk memuaskan dan memenuhi kehendak para pihak yang bersengketa. Pihak yang kalah akan mengatakan bahwa putusan arbiter tidak adil, demikian pula sebaliknya (pihak yang menang akan mengatakan putusan itu adil). Ketergantungan terhadap para arbiter merupakan suatu kelemahan karena substansi perkara dalam arbitrase tidak dapat diuji kembali (melalui proses banding); mengingat putusan arbitrase bersifat final dan mengikat.

Ketiga, tidak ada preseden putusan terdahulu. Tidak adanya legal precedence atau keterikatan terhadap putusan-putusan arbitrase sebelumnya. Artinya, putusanputusan arbitrase atas suatu sengketa terbuang tanpa manfaat, meskipun di dalamnya mengandung argumentasi-argumentasi berbo bot dari para arbiter terkenal di bidangnya. Hilangnya precedence tersebut dapat menimbulkan putusan-putusan yang saling berlawanan atas penyelesaian sengketa serupa di masa yang akan datang.

Keempat, masalah putusan arbitrase asing. Penyelesaian sengketa melalui arbitrase internasional memiliki hambatan sehubungan dengan pengakuan dan pelaksanaan putusannya. Kesulitan itu menjadi masalah yang sangat penting karena biasanya di negara pihak yang kalah terdapat harta yang harus dieksekusi. O leh karena itu, berhasil tidaknya penyelesaian sengketa berkaitan erat dengan dapat tidaknya putusan arbitrase tersebut dilaksanakan di negara dari pihak yang dikalahkan. ${ }^{32}$

D alam setiap perjanjian kontrak ekonomi syariah sebaiknya mencantumkan klausul penyelesaian sengketa melalui musyawarah, mediasi, dan arbitrase, atau ke lembaga peradilan sebagai pilihan terakhir. Apabila para pihak sepakat menempuh proses arbitrase dalam penyelesaian sengketanya maka sebaiknya mencantumkan Basyarnas sebagai lembaga arbiter yang menangani penyelesaian perselisihan sengketa mereka.

\section{Penyelesaian melalui Proses Persidangan}

Berdasarkan peraturan perundang-undangan yang ada, maka penyelesaian sengketa yang melalui peradilan harus melalui pengadilan agama. Namun, jika para pihak menentukan lain, yakni penyelesaian sengketa di luar pengadilan agama, baik melalui pengadilan umum, arbitrase, dan cara-cara lain, maka hal itu juga tidak bisa disalahkan, dengan syarat; 1) sudah disepakati bersama oleh para pihak dalam akad, 2) penyelesaian sengketa tadi tidak boleh bertentangan dengan prinsip syariah, seperti adanya penyuapan untuk memenangkan perkara. Sebenarnya, syarat nomor dua ini juga berlaku dalam pengadilan agama. Hanya saja, sejak awal pengadilan agama sudah dirancang untuk menjunjung tinggi Prinsip Syariah, sehingga UU Perbankan Syariah tidak mempertegasnya lagi.

Manakala upaya damai tidak membuahkan hasil, maka hakim harus melanjutkan pemeriksaan perkara tersebut sesuai dengan ketentuan hukum acara yang berlaku. D engan demikian, perkara tersebut akan diperiksa dan diselesaikan melalu proses persidangan

\footnotetext{
${ }^{32} \mathrm{G}$ atot Soemartono, ArlitrasedanMeelas di Indonesia(Jakarta: Gramedia Pustaka Utama, 2006), 14-15.
} 
(litigasi) sebagaimana mestinya. Penyelesaian perkara perbankan syariah di lingkungan peradilan agama akan dilakukan sesuai dengan ketentuan hukum acara perdata sebagaimana yang berlaku di lingkungan peradilan umum. D engan demikian dalam hal ini proses pemeriksaan perkara tersebut akan berjalan sebagaimana lazimnya proses pemeriksaan perkara perdata di pengadilan yang secara umum akan dimulai dengan pembacaan surat gugatan penggugat, lalu disusul dengan proses jawab menjawab yang akan diawali dengan jawaban dari pihak tergugat, kemudian replik penggugat, dan terakhir duplik dari pihak tergugat.

Setelah proses jawab menjawab tersebut selesai, lalu persidangan dilanjutkan dengan acara pembuktian. Pada tahap pembuktian ini kedua belah pihak beperkara masing-masing mengajukan bukti-buktinya guna mendukung dalil-dalil yang telah dikemukakan di persidangan. Setelah masing-masing pihak mengajukan bukti-buktinya, lalu tahap berikutnya adalah kesimpulan dari para pihak yang merupakan tahap akhir dari proses pemeriksaan perkara di persidangan.

Setelah seluruh tahap pemeriksaan perkara di persidangan selesai, hakim melanjutkan kerjanya untuk mengambil putusan dalam rangka mengadili atau memberikan keadilan dalam perkara tersebut. Untuk itu tindakan selanjutnya yang harus dilakukan hakim dalam memeriksa dan mengadili perkara tersebut adalah melakukan konstatir, mengkualifisir, dan meng-konstitir guna menemukan hukum dan menegakkan keadilan atas perkara tersebut untuk kemudian disusun dalam suatu putusan (vomis) hakim.

Adapun kerangka kerja dari ketiga hal tersebut sebagai acuannya paling tidak diuraikan oleh Arto, ${ }^{33}$ yaitu: pertama, meng-kanstatir artinya menguji benar tidaknya peristiwa atau fakta-fakta yang diajukan para pihak melalu pembuktian menggunakan alat-alat bukti yang sah menurut hukum pembuktian. Hal ini harus diuraikan secara sistematis dalam putusan hakim pada bagian duduk perkaranya, kedua, meng-kualifisir, artinya menilai peristiwa atau fakta yang telah terbukti itu termasuk hubungan hukum apa dan menemukan hukumnya bagi peristiwa yang telah dikotatir. Hal ini harus diuraikan dalam putusan hakim pada bagian pertimbangan hukumnya, dan ketiga, meng-konsituir yakni menetapkan hukum atas perkara tersebut. D alam hal ini hakim 1) menetapkan hukum atas perkara tersebut dalam amar putusannya, 2) mengadili sebatas petitum yang ada, kecuali ditentukan lain oleh undang-undang, dan 3) menetapkan biaya perkara. D emikian secara garis besar prosedur pemeriksaan perkara perbankan syariah di pengadilan agama sesuai dengan ketentuan hukum acara yang berlaku.

\section{Penutup}

Ruang lingkup kewenangan lingkungan peradilan agama dalam bidang perbankan syariah, meliputi seluruh perkara perbankan syariah di bidang perdata. D alam hal ini seluruh sengketa perdata yang terjadi antara bank syariah dengan pihak mana pun, termasuk yang terjadi antara bank syariah dengan pihak non-Islam tersebut adalah kewenangan lingkungan peradilan agama. Begitu juga setiap sengketa ekonomi syariah yang dilakukan oleh pihakpihak yang melakukan perjanjian atau perikatan syariah merupakan perkara di bawah

\footnotetext{
${ }^{33}$ A. Mukti Arto, Praktik Pekkara PerdataPada PengadlanAgama(Yogyakarta: Pustaka Pelajar, 1996), 33, 36-37.
} 
kewenangan lingkungan peradilan agama, kecuali yang dengan tegas ditentukan lain dalam undang-undang. Misalnya terhadap sengketa yang timbul dari perjanjian yang mengandung klausula arbitrase. D alam hal ini pengadilan agama tidak berwenang mengadilinya.

Selain dengan jalur arbitrase, pihak-pihak yang beperkara juga dapat menempuh cara damai berupa musyawarah atau mediasi. Jadi, teknik penyelesaian perkara ekonomi syariah tersebut di lingkungan pengadilan agama dapat ditempuh dengan dua cara yaitu: diselesaikan melalui perdamaian, atau apabila perdamaian tidak berhasil, maka harus diselesaikan melalui proses persidangan sebagaimana mestinya. Kedua cara di atas sebenarnya tidak jauh berbeda dengan penyelesaian sengketa dalam tradisi Islam dan peraturan tata hukum di Indonesia sebelum berlakunya ketentuan UU No. 3 Tahun 2006 tentang kewenangan Peradilan Agama dan PERMA No. 01 tahun 2008 mengenai proses musyawarah, mediasi, arbitrase dan penyelesaian dengan proses peradilan agama.

\section{Daftar Rujukan:}

Abbas, Syahrizal. Medias dalamPespaktif Hukum Syaniah, HukumAdat dan HukumNasional, ed. Agustina Arida dan Luthfi Aunie. Jakarta: Prenada Media Group, 2009.

Adam, Siti Megadianty dan Rahmadi, Takdir. "Sengketa dan Penyelesaiannya," Buletian Musjawarah No. 1, Thn. 1. Jakarta: Indonesian Centre for Environmental Law, 1997.

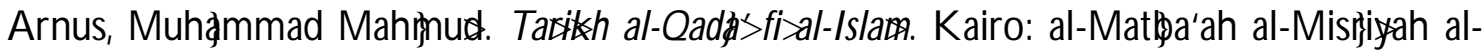
Hądithah, 1987.

Arto, A. Mukti. Praktik Pekara Perdata Pada Pengadilan Agama. Yogyakarta: Pustaka Pelajar, 1996.

Badrulzaman, Mariam Darus. "Peranan BAMUI dalam Pembangunan Hukum Nasional," dalam Abdul Rahman Saleh, et al., ArditraseIdamIndonesia Jakarta: BAMUI kerjasama dengan Bank Muamalat, 1994.

Basir, Cik. Perydeaian Sengkta Pedbankan Syariah di Pengadlan Agama \& Mahkamah Syariah Jakarta: Kencana, 2009.

Fuady, Munir. Anditrase Nasional. Bandung: PT. Citra Aditya, 2000.

Gautama, Sudargo. UndangUndang Arditrase Banu Bandung: PT. Citra Adtya Bakti, 1999.

Harahap, M. Yahya. HukumAcara Peckata Jakarta: Sinar G rafika, 2005.

Muhammad, A bdulkadir. Pengantar Hukum Penusahaan Indonesia Bandung: PT. Citra Bakti, 1993.

Muhł̧mmad, Imam Taqi`al-D in AbußBakr ibn. Kifayat al-Akhyar. Bandung: al-Ma'arif, t.th. Rahim, Abdul. the Priniples Muhammadan Junispudane London: Luzac \& Co, 1991.

Rosyadi, A. Rahmadi dan Ngatino. ArditrasedalamPespaktif IslamdanHukumPositif Bandung: Citra Aditya Bakti, 2002.

Sabiq, Sayyid. Fiqh al-Sumah Juz 3. Kairo: Das al-Fath, 2000.

Shidiqi (Ash), Hasbie. Pengantar Fiqh Muamalah Jakarta: Bulan Bintang, 1984.

Soemartono, G atot. Arditrase dan Meelasi d Indonesia Jakarta: Gramedia Pustaka Utama, 2006.

Suparman, Eman. Pilihan FonumA ditrase dalamSengketa Komersial untuk Penegakan Keadilan Jakarta: PT. Tatanusa, 2004.

Suyutij(al), Jalaz al-D in. al-Ashbah wa al-Naz'd'ir fi al-Funu’ Jakarta: as-Fakofah al-Islamiyah, 
360 Perjanjian Syariah pada Lembaga Keuangan Syariah

t.th.

Syuaibun. "Alternatif Penyelesaian Sengketa dalam Perspektif Undang-Undang Nomor 30 Tahun 1999." Istislah: Jumal HukumIslam Vol. 3, No. 1 (Januari-Juni 2004).

Widjaja, G unawan dan Yani, Ahmad. Sei Hukum Bisnis Hukum Anbitrase Jakarta: PT. RajaG rafindo Persada, 2001.

Wirdyaningsih et al. Bank dan Asuransi Isamdi Indonesia Jakarta: Prenada Media Group, 2005.

Zarqa>(al), Mustłgfa>A hmad. al-Madkhal ilaral-Fiqh al-'Amal-Isamfi Thaubih al-Jadid Beirut: D ał al-Fikr, 1965.

Zuhłgyli>(al), Wahbah. al-Fiqh al-Isami wa Adillatuh Juz 5. Beirut: Das al-Fikr, 2003. 